\title{
Fluoroquinolone resistance among CTX-M producing uropathogenic Escherichia coli from HIV and non-HIV patients in South India
}

\author{
Kesavaram Padmavathy ${ }^{1,2 *}$, Padma Krishnan $^{2}, \mathrm{~S}_{\text {Rajasekaran }}^{3}$ \\ From 2nd International Science Symposium on HIV and Infectious Diseases (HIV SCIENCE 2014) \\ Chennai, India. 30 January - 1 February 2014
}

\section{Background}

Extended spectrum $\beta$-lactamase (ESBL) especially, the CTX-M producing Escherichia coli has emerged world wide as the leading cause of community onset UTI in the era of antibiotic resistance. The CTX-M producers often exhibit co-resistance towards fluoroquinolones and are a growing challenge to patient care. The purpose of this study was to determine the incidence of fluoroquinolone resistance among CTX-M producing uropathogenic E.coli (UPEC).

\section{Methods}

UPEC isolated from HIV $(\mathrm{n}=76)$ and non-HIV antenatal patients $(n=42)$ were screened for ESBL production as per CLSI guidelines. bla $a_{C T X-M}$ was detected by PCR. Susceptibility to ciprofloxacin was assessed as per CLSI guidelines. Fisher's exact test (two tailed) was employed to analyze the statistical significance of the results.

\section{Results}

ESBL producers were more common among the UPEC isolates from HIV compared to those from non-HIV patients ( $75 \%$ vs $52.4 \%, \mathrm{p}=0.015$, OR $=2.7273$ ). Significant difference was observed in the incidence of $b l a_{C T X-M}$ among the ESBL producers from HIV and non-HIV patients $(70.2 \%$ vs $31.8 \%, p=0.002$, $\mathrm{OR}=5.042)$. Compared to the CTX-M non-producers, majority of the CTX-M producers were resistant to ciprofloxacin in both the groups (HIV, 92.5\% Vs 58.8\%, $\mathrm{p}=0.0037$, OR $=8.6333$, and non-HIV, $71.4 \%$ vs $20 \%, \mathrm{p}=0.5235, \mathrm{OR}=10$ ).

\footnotetext{
* Correspondence: padmabakianath@gmail.com

'Sree Balaji Dental College and Hospital, Bharath University, Chennai, India Full list of author information is available at the end of the article
}

\section{Conclusion}

Fluoroquinolones are the most common non- $\beta$ lactam antibiotic used in the treatment of infections caused by ESBL producing organisms. The results of our study suggest the possible emergence of plasmid mediated fluoroquinolone resistance among the CTX-M producing E. coli. The co-resistance exhibited by the CTX-M producers is a cause of concern, as it might facilitate the co-selection process.

\section{Authors' details}

${ }^{1}$ Sree Balaji Dental College and Hospital, Bharath University, Chennai, India. ${ }^{2}$ Dept of Microbiology, Dr. ALM PGIBMS, University of Madras, Chennai, India. ${ }^{3}$ Government Hospital of Thoracic Medicine, Chennai, India.

Published: 27 May 2014

doi:10.1186/1471-2334-14-S3-P63

Cite this article as: Padmavathy et al:: Fluoroquinolone resistance among CTX-M producing uropathogenic Escherichia coli from HIV and non-HIV patients in South India. BMC Infectious Diseases 2014 14(Suppl 3): P63.

Submit your next manuscript to BioMed Central and take full advantage of:

- Convenient online submission

- Thorough peer review

- No space constraints or color figure charges

- Immediate publication on acceptance

- Inclusion in PubMed, CAS, Scopus and Google Scholar

- Research which is freely available for redistribution

Submit your manuscript at www.biomedcentral.com/submit
() Biomed Central 